\title{
New Educational Trends Connected with the Development of Media and Innovative Technologies - A Few Reflections on the Future Perspectives on Learning and Teaching
}

\author{
Monika Frania PhD \\ University of Silesia, Katowice, Poland \\ Pedagogy, Education, Media \& Communication \\ monika.frania@us.edu.pl
}

Doi:10.5901/jesr.2014.v4n4p232

\begin{abstract}
The article traverses the new trends, selected methods and directions that are present in school and out of school education. The author analyzes the Polish examples and tries to relate them to the reality of the world education. Today's society is called 'information society', 'knowledge society' and but also 'network society'. The development of the media and new technologies has caused that today's teacher and student of all ages can enjoy a variety of tools to improve communication, gathering information and learning. The purpose of reflection is to identify what are the coming major trends in e-learning and education generally that will make an impact upon education in Poland (key issues: mobile learning; use of transmedia storytelling and WebQuest in education; gamification; new assessment tools such as e-portfolios and badges; blended learning as a method of learning; TED and Khan Academy as an educational sources; MOOC; OER; flipped classroom; The Learning Analitics).
\end{abstract}

Keywords: education, new technology, trends, media

\section{Introduction}

Human as a social being has been learning since ages. Education has been changing its form over the centuries; models and ways of gaining knowledge have been transformed, yet it still constitutes the basis for the development of individuals and entire societies. The access to information and knowledge is associated with power, the potential for innovative development and the improvement of social conditions. The process of learning is also a cognitive operation related to understanding, remembering and acquiring (Strelau, 2007). The process of teaching is connected with upbringing, providing some role models and sharing values (Łobocki, 2009). Finally, institutional education in a given country is related to the mainstream of the education policy. Due to the aforementioned reasons which, however, do not exhaust the whole subject, education is an important element of an analysis of various branches and fields of science and administrative solutions. A proper consideration is given to the subject by both practitioners and theoreticians. By means of formal and informal education, teachers and learners jointly create a space for mutual improvement. The contemporary reality can be described as a society of knowledge. Institutions, including schools in particular, play a crucial role in this context.

Now, it is a special moment for the modern education. Due to the development of modern technologies, ICT tools and functioning in a world called "media-based civilisation" (Goban-Klas, 2005), the process of teaching and learning can be supported, and sometimes even mediated, by vast instrumentation. It leads to a change in models and paradigms. The teacher-student relation undergoes a metamorphosis. This article presents an overview of the increasing current and future trends in education, in relation to the reports: The NMC Horizon Report: 2013 Higher Education Edition (Johnson, Adams Becker, Cummins, Estrada, Freeman, Ludgate, 2013), The NMC Horizon Report: 2014 Higher Education Edition (Johnson, Adams Becker, Estrada, Freeman, 2014b) and The NMC Horizon Report: 2014 K-12 Edition (Johnson, Adams Becker, Estrada, Freeman, 2014a), as well as to examples from the Polish reality and experiences, which fit into the described directions of changes.

\section{E-Learning, Mobile Learning and Blended Learning in Education}

Today, traditional classroom teaching tends to be supported or completely replaced by various forms of distance learning. In many countries the trend is pervasive, and it is even expected to develop further. E-learning is a form of didactics supported by computers and network communication, enabling students to complete a course or a series of classes etc. without the requirement of being physically present in a classroom. According to B. Holmes and J. Gardner (2006), e- 
learning demands comprehensive involvement of its participants, which means that some basic abilities and skills such as searching for information, understanding, creating, discovering, analysing, discussing and cooperating are practised. E-learning courses are conducted online, both via the training institution's internal network (the Intranet) and via external network (the Internet). They encompass sharing knowledge, control over the process and feedback. Two models are the most common: web-based learning in synchronous and asynchronous approach, using the Internet and computer-based learning, in which such devices as CD and DVD are applied. Concurrently, the blended learning model is used, which is complementary teaching (Szabłowski, 2009). In this model, traditional teaching with a direct contact between the teacher and student is complemented by an equally important online part and/or supported by ICT. As far as Polish schools and universities are concerned, education is often supported by elements of e-learning with the use of the Moodle platform. It is open source software on the GNU General Public License that is offered free of charge. It allows for modifications and adjustments to the user's own needs, which, together with a user-friendly and clear interface, contributes to its educational and evaluative usage. The courses offered by lecturers from the University of Silesia in Katowice, Faculty of Philology (http://el1.us.edu.pl/wf/) could serve as an example.

The development of ICT instrumentation goes along with the advancements in miniaturisation of devices. Large desktop computers have been replaced with smaller devices such as: laptops, notebooks or palmtops. Smartphones are also in common use in Poland. The use of mobile technology should be no longer considered a future trend but rather an educational reality. Special devices, software and apps make it possible to learn in almost any place - at home, at school, during a journey, and at any time, according to the rule: "anywhere, anytime access to learning materials" (KukulskaHulme, Traxler, 2005). Additionally, many of them are based on the idea of edutainment, combining education with entertainment, in the form of quizzes, crosswords, plays, etc. An example of research on using mobile technology as a method of supporting traditional learning are my explorations of the QMindShare ${ }^{T M}$ application (Frania, 2013). Applying this device has allowed the participants of this pedagogical experiment to actively revise units in an attractive and effective form.

\section{Flipped Classroom and Change in the Role of the Teacher}

Another constantly increasing trend in the educational reality is the so-called flipped classroom teaching model (Johnson, Adams Becker, Estrada, Freeman, 2014b). The time a student spends at school during classes is dedicated to active group work, practice and vivid discussions with peers and the teacher. An educator in a classroom does not share or lecture any new part of material, but rather offers the possibilities for exploring and profound understanding of a given problem. New information is acquired by students in a theoretical form during their individual work at home, for example, while reading books, watching video materials or discussing via social media platforms. Simplifying and concluding, in the traditional model "a student listens to/reads, acquires new material in a classroom, and practices it at home", while in the flipped classroom model "a student reads and acquires material at home, and practises it at school". The Khan Academy or TedEd videos are a useful source of knowledge in this model. This approach promotes discussions and reflections on various levels (Keengwe, Onchwari, Oigara, 2014). The model has both advantages and disadvantages. It allows students to profoundly understand an issue, the teacher is given the possibility to explain a problem/task to each student individually. However, acquiring knowledge independently outside the school environment requires a lot of perseverance and motivation.

What is more, the role of the teacher has changed (Johnson, Adams Becker, Estrada, Freeman, 2014a) - from the position of a mentor to a guide or partner. The distance between the two subjects of the teaching-learning process has been significantly reduced. In such a case, the authority has to be built in a different way than in the case of directive teaching with the use of expository methods mainly. In the discussed model, activating methods dominate.

In the Polish educational reality, in primary schools, lower secondary schools and secondary schools, the flipped classroom model is used very rarely. A course designed by the University of Silesia in Katowice for secondary school graduates as potential future students of the University, the so-called "Secondary school final exam revisions" ((http://maturzysta.us.edu.pl) could serve as an example of the idea being put into practice.

\section{Gamification and Edutainment - New or Old Phenomena?}

Games and plays have been present in education since ages, however, new technologies have changed the nature of this presence. Game-based learning and gamification introduce the mechanisms of games into different operating areas. It is a crucial aspect and it has been widely discussed for a few years now (Johnson, Adams Becker, Estrada, Freeman, 2014a). The capacity of the term allows confining to it the use in education, of simple games dedicated to mobile devices 
and computer games, as well as platforms, where players from all over the world can interact and learn by cooperation (e.g. MMO games). Such mechanism as: scoring points, collecting digital badges, reaching next levels of competence, competing and cooperation need to be mentioned as well. The role of such consoles as Microsoft Kinect or Nintendo Wii, which combine real activities with games by means of coordinated movements, is emphasized (Johnson, Adams Becker, Estrada, Freeman, 2014b). Educational LARP games (live actin role-playing games) are also a part of this trend. They consist in the participants taking on roles, and the whole thing is based only on a general idea - without a detailed script.

An example close to my teaching experience is an attempt to implement ARGs - Alternate Reality Games into the process of education. In this type of games, the players work together in the real world in order to find a solution and try to meet the challenge by using various media platforms. The real world provides experience in the game and becomes a field, that is the next layer of the game (Piatt, 2012). The transmedia storytelling is used. In 2014, during optional courses with students preparing for the profession of a teacher (University of Silesia, Faculty of Pedagogy), I started a series of game design workshops, aimed at designing educational games. It was just the first stage of the process, in which the participants were supposed to create complex game scripts with the layers of media aids. So far, such initiatives have been rare in Poland. Other elements related to game-based learning and gamification enjoy greater popularity, but still they dominate only in informal education.

\section{Metamorphosis of Educational Resources}

As the reports' authors emphasize, openness is the key word in the context of modern educational resources (Johnson, Adams Becker, Cummins, Estrada, Freeman, Ludgate, 2013). I would also add to it the term: collaboration, in relation to learning in cooperation and creating commonly available resources such as wiki. The character of the educational resources is changing and it can be predicted that it will affect various aspects. More often it is social media which are becoming the contact platform between participants in education. According to S. Juszczyk (2012), they may contribute to the development of many necessary and useful professional, social, cultural and technological competences. The professional materials prepared by publishing houses or other publishing institutions, and revised by experts, are complemented by amateur writing, audio and video products. A lot of content has already emerged thanks to learning with the use of social media or participation in courses such as MOOC. They are easily available and often have digital versions as well as multimedia character. A significant part is placed to, for example, the Khan Academy or TED.

OER, Open Educational Resources, are most often materials with full and free access on the basis of the Creative Commons license, a public domain, or others. A Polish example of a website which provides a base of information on such resources is: http://otwartezasoby.pl/. An example of the European initiative which promotes innovative learning is: http://www.openeducationeuropa.eu/, where the resources, MOOC, courses, blogs and information on initiatives as well as on institutions can be found.

The openness of resources, education, information, but also open software and free licenses provide a good chance to improve the quality of the learning process and make it more attractive. An educator has the possibility to use such kind of resources in order to make a traditional classroom lesson more appealing, by preparing e-learning elements or WebQuests for children or teenagers. However, some threats are related to it, for example, the use of unreliable or inadequate contents and susceptibility to manipulation. The legal and ethical issues concerned with copyrights may arise as a serious problem, due to the fact that there are no universal, common or highly regarded regulations established on this issue. It should be remembered that in Poland it is stated by the rule of presumption that any shared or published (also on the Internet) content has "all rights reserved", unless clearly stated otherwise (as quoted in: Kozierski, Kabaciński, Lis, Kaczmarek, 2013).

Therefore, the aforementioned increasing trend requires a constant development of adequate competences: as far as school is concerned, an adequately performed role of a modern teacher as well as an adequate level of media literacy and information literacy.

\section{New Gadgets and Tools}

In the Polish formal and informal educational reality, gadgets such as wearable technology or tools based on AR, Augmented Reality, which combines the real world with the world generated by computers, are rather distant solutions. Smart jewellery, piece of clothing or glasses such as Google Glass or Vuzix M100 are for an average Polish pupil, student or teacher an element of an abstractive future. Slightly more frequent in use are smartwatches, however the entertainment function is still prevalent among them. As the authors of the annual report The NMC Horizon Report (Johnson, Adams Becker, Cummins, Estrada, Freeman, Ludgate, 2013) emphasise, the amount of wearable devices 
among users increases almost every day and, even though the education field has only started to experiment with them, still they are potentially useful gadgets, for example at universities. Their significance may in the first place influence the efficiency factor, as the devices of this type will significantly save time, for example they can automatically send necessary information via text messaging, e-mails or social networks reacting to user's voice commands, gestures or various other orders, help students and teachers to communicate or follow the updates of educational information and help to react quickly to notifications sent online (Johnson, Adams Becker, Cummins, Estrada, Freeman, Ludgate, 2013). It can only be presumed that the launch of these gadgets into schools or universities on a mass scale may cause a revolution in the previous learning model and in the flow of information between the educator and learner. It is also related to the dissemination of the BYOD idea (Bring Your Own Device), according to which students should work and learn in the institutional environment by means of their own devices they also use in the non-school environment (Johnson, Adams Becker, Estrada, Freeman, 2014a).

New technologies and applications can be also used in the process of evaluation and grading progresses. According to predictions, traditional grades and descriptive marks may soon be replaced with e-portfolios and digital badges, however it is surely difficult for Polish students to imagine that instead of certificates they might receive a set of digital badges on their media platform profiles.

\section{Matching Education to the Needs or a Tool of Manipulation?}

The Learning Analitics, an educational application for monitoring user's online activity, employed so far in business, will be used in broadly understood education within the period of the next two or three years (Johnson, Adams Becker, Estrada, Freeman, 2014a). The great amount of data on using online portals and websites, communication and making choices will form a base for analyses and conclusions, which later will serve in designing individually customized sources and educational resources. Due to this fact, teaching will take a more customized form, both in the traditional and elearning version. At this moment, no examples of this phenomena in the Polish educational system can be provided. A sceptical approach remains in relation to the ultimate complete rejection of education confinements or curricula. This method can also raise some ethical objections.

\section{Conclusion}

Media and new technologies are changing the learning landscape and we are not capable of stopping this process. The trends and tendencies discussed in the article are presumably not the only ones, which individuals connected with education and training courses as well as all of us will have to face, as we all gain new knowledge every day. The above summary constitutes a subjective selection and an attempt to relate them to the examples in the Polish reality. However, not all phenomena are still strongly present or noticeable.

The educational environment will be able to find chances in the context of ICT and media development, but it will also have to face some potential threats. However, the key word is here the term change. The change will be present. It will affect the relation between the participants of the process of education, the form and methods of work with a student, and the education policy. Perhaps, the change will be necessary in the education system and education policy. So far, the set of the key competences of a European citizen has included among others: IT competences, i.e. concentrated on searching, processing and collecting information and its using in a critical and systematic way, and on creating and presenting, as well as on using information and communication technologies in critical thinking and creating innovations (Huk, 2008). Perhaps, it is not enough and the change will have to affect also a set of basic skills.

The development of technology is very rapid and education can benefit from it. However, both the authors of ICT tools and their users must remember that by shifting the horizons of technology assisted teaching, we also deepen the gap between the digitally active and technologically passive users. The number of people excluded from information updates is rising, due to the fact they do not have access to new tools, methods or applications for social, economic or political reasons.

\section{References}

Frania, M. (2013). The Role of Mobile Technology in Supporting the Learning Process of Adults in the 'Network Society', Journal of Educational \& Social Research, vol 3, no. 7, pp. 556-562.

Goban-Klas, T. (2005). Cywilizacja medialna. Geneza, ewolucja, eksplozja. Warszawa: WSiP S.A.

Holmes, B. \& Gardner, J. (2006). E-Learning: Concepts and Practice. London-California-New Delhi: SAGE Publications. 
Huk, T. (2008). Komputer w procesie kształtowania umiejętności kluczowych. Warszawa: Difin.

Johnson, L. \& Adams Becker, S. \& Estrada, V. \& Freeman, A. (2014a). NMC Horizon Report: 2014 K-12 Edition. Austin, Texas: The New Media Consortium. http://cdn.nmc.org/media/2014-nmc-horizon-report-k12-EN.pdf [6.06.2014].

Johnson, L. \& Adams Becker, S. \& Estrada, V. \& Freeman, A. (2014b). NMC Horizon Report: 2014 Higher Education Edition Austin, Texas: The New Media Consortium, http://www.nmc.org/pdf/2014-nmc-horizon-report-he-EN.pdf [6.06.2014].

Johnson, L. \& Adams Becker, S. \& Cummins, M. \& Estrada, V. \& Freeman, A. \& Ludgate, H. (2013),. NMC Horizon Report: 2013 Higher Education Edition, Austin, Texas: The New Media Consortium, http://www.nmc.org/pdf/2013-horizon-report-HE.pdf [9.06.2014].

Juszczyk, S. (2012). Media społeczne w procesie kształcenia studentów. In B. Siemieniecki. (Ed.), Edukacja medialna w świecie ponowoczesnym. Toruń: Wydawnictwo Naukowe Uniwersytetu Mikołaja Kopernika.

Keengwe, J. \& Onchwari, G. \& Oigara, J.N. (2014). Promoting Active Learning Through the Flipped Classroom Model. Hershey: IGI Global.

Kozierski, P. \& Kabaciński, R. \& Lis, M. \& Kaczmarek, P. (2013). Open Access: Analiza zjawiska z punktu widzenia polskiego naukowca. Poznań-Kraków: Impuls.

Kukulska-Hulme, A. \& Traxler, J. (Ed.) (2005). Mobile Learning: A Handbook for Educators And Trainers. London \& New York: Routledge Taylor\&Francis Group.

Łobocki, M. (2009). Teoria wychowania w zarysie. Kraków: Impuls.

Piatt, K. (2012). Developing Alternate Reality Games for Learning. In N. Whitton. A. Moseley (Ed.), Using Games to Enhance Learning and Teaching. A Beginner's Guide. New York: Routledge.

Strelau, J. (2007). Psychologia - podręcznik akademicki. Psychologia ogólna. Gdańsk: GWP.

Szabłowski, S. (2009) E-learning dla nauczycieli. Rzeszów: Wydawnictwo Oświatowe FOSZE. 